\title{
Implementasi Dempster Shafer Dalam Diagnosa Penyakit Impetigo Pada Balita
}

\author{
Asyahri Hadi Nasyuha1, Moch. Iswan Perangin Angin², Marsono, ${ }^{1, *}$ \\ ${ }^{1}$ Prodi Sistem Informasi, STMIK Triguna Dharma, Medan, Indonesia \\ ${ }^{2}$ Prodi Manajemen Informatika, STMIK Triguna Dharma, Medan, Indonesia \\ Email: ${ }^{1}$ ayi.nasyuha@ gmail.com, ${ }^{2}$ mochammadiswan@gmail.com, ${ }^{3}$ marsonotgd@yahoo.com \\ Email Penulis Korespondensi: ayi.nasyuha@gmail.com
}

\begin{abstract}
Abstrak-Diagnosa impetigo dengan menggunakan sistem pakar yang menggunakan sumber kepakaran bertujuan untuk mendapatkan informasi yang akurat yang sesuai dengan gejala yang diderita oleh pasien, analsisi sistem pakar ini menggunakan metode dempster shafer dengan teori matematika untuk pembuktian berdasarkan belief function and plausible reasoning (fungsi kepercayaan dan pemikiran yang masuk akal yang digunakan untuk mengkombinasi potongan informasi yang terpisah (bukti) untuk mengkalkulasi kemungkinan dari suatu peristiwa yang mampu menghasilkan informasi dari pakar mengenai gejala dan solusi dari penyakit gejala impetigo secara akurat dan membangun suatu program aplikasi sistem pakar yang mampu mendiagnosa secara dini impetigo pada balita serta memberikan solusi dan informasi dengan cepat.
\end{abstract}

Kata Kunci: Impetigo pada Balita, Sistem Pakar, Dempster Shafer

\begin{abstract}
The diagnosis of impetigo by using an expert system that uses the source of expertise aims to obtain accurate information in accordance with the symptoms suffered by the patient, this expert system analysis uses the dempster shafer method with mathematical theory for proof based on belief function and plausible reasoning it makes sense to combine separate pieces of information (evidence) to calculate the likelihood of an event that can produce information from experts about the symptoms and solutions of impetigo symptoms accurately and build an expert application system program that is able to diagnose early impetigo in infants and provide solutions and information quickly.
\end{abstract}

Keywords: Impetigo in Toddlers, Expert Systems, Dempster Shafers.

\section{PENDAHULUAN}

Daya tahan tubuh dan kulit pada balita lebih rentan untuk terkena beragam penyakit kulit yang diakibatkan oleh infeksi virus, bakteri, jamur, maupun parasit. Salah satu penyakit kulit yaitu penyakit Impetigo. Impetigo adalah suatu pioderma (infeksi kulit akibat bakteri Staphylococcus, Streptococcus, atau keduanya). Penyakit ini sangat menular dan sering dijumpai pada anak balita. Impetigo pada anak berusia kurang dari 6 tahun lebih tinggi dari pada orang dewasa, namun sebenarnya impetigo dapat terrjadi pada semua usia. Impetigo terjadi lebih sering terjadi di iklim tropis dan di dataran rendah. Kondisi hangat dan lembab lebih rentan terkena gangguan kulit. Kondisi kebersihan yang buruk juga menyebabkan impetigo. Impetigo dapat mengenai semua ras. Impetigo terjadi pada individu-individu dari segala usia, tetapi paling sering terjadi pada anak usia 2-5 tahun[1]. Penyebaran cepat dapat terjadi melalui keluarga, pusat penitipan anak, dan sekolah. Impetigo lebih jarang terjadi pada orang dewasa, biasanya bersamaan dengan kondisi kulit atau infeksi lain dan lebih sering terjadi pada pria. Pada umumnya, impetigo dapat sembuh sendiri seiring waktu. Penularan bakteri penyebab impetigo dapat terjadi melalui kontak fisik langsung dengan bayi yang memiliki impetigo atau melalui perantara, seperti baju, handuk, serbet, dan sebagainya yang sebelumnya dipakai bersama.

Impetigo memiliki dua jenis yang berbeda seperti Impetigo Bulosa adalah jenis penyakit impetigo yang sering menyerang pada bayi, ditandainya dengan kelainan pada kulit dan cairan yang keluar pada kulit yang mengakibatkan infeksi kulit kronis. Dan Impetigo Krustosa adalah jenis impetigo yang manifestasi gejalanya dapat menular dari serangan udara, penyakit ini juga dikenal sebgai penyakit yang sering di derita oleh orang yang memiliki tingkat kebersihan yang rendah dan faktor lingkungan yang kurang baik.

Beberapa kasus impetigo bisa sembuh dengan sendirinya dalam jangka waktu dua sampai tiga minggu tanpa diobati. Namun, resep antibiotik dari dokter dapat mempercepat penyembuhan menjadi 7-10 hari. Ini juga dapat mempersempit risiko penularan pada bayi dan anak-anak lain di sekitarnya. Impetigo bisa diobati dengan menggunakan antibiotik oles maupun antibiotik minum. Antibiotik oles digunakan jika infeksi yang terjadi masih ringan, berada pada satu area, dan belum menyebar ke mana-mana.Antibiotik minum digunakan jika gejala impetigo tidak bisa ditangani dengan antibiotik oles, kondisinya semakin parah, dan menyebar ke bagian lainnya.

Jika pengobatan dengan antibiotik tidak berpengaruh setelah tiga hari, dokter akan melakukan pemeriksaan sampel kulit yang terinfeksi di laboratorium untuk melihat kemungkinan adanya infeksi penyakit lain selain impetigo. Pemeriksaan laboratorium juga perlu dilakukan jika impetigo kambuh lagi. Biasanya impetigo kambuh karena masih ada bakteri yang bersarang di area tertentu, seperti hidung, sehingga mudah menginfeksi daerah sekitarnya yang kebetulan mengalami luka.Jika terbukti benar, maka bakteri tersebut harus dibasmi dengan obat antiseptik khusus yang dapat digunakan pada hidung. Sistem pakar (expert system) merupakan suatu perangkat lunak komputer yang mempunyai dasar pengetahuan sebagai domain khusus dan menggunakan penalaran inferensi yang hamper sama dengan seorang pakar dalam penyelesaian masalah[2].Sistem pakar adalah program kecerdasan buatan yang berusaha mengadopsi pengetahuan manusia ke 
computer, agar computer dapat menyelesaikan masalah seperti yang biasa dilakukan oleh para ahli. Sistem pakar diharapkan dapat bekerja dalam semua hal seperti seorang pakar. Sistem pakar merupakan cabang dari Artificial Intelligence (AI) yang cukup tua karena sistem ini mulai dikembangkan pada pertengahan 1960. Sistem pakar yang mucul pertamaka kali adalah General-purpose problem solver (GPS) yang dikembangkan oleh Newel dan Simon. Sistem pakar (Expert System) adalah aplikasi berbasis komputer yang digunakan untuk menyelesaikan masalah sebagaimana yang dipikirkan oleh pakar.pakar yang dimaksud disini adalah orang yang mempunyai keahlian khusus yang dapat menyelesaikan masalah yang tidak dapat diselesaikan oleh orang awam. Contohnya, dokter adalah seorang pakar yang mampu mendiagnosa penyakit yang diderita pasien serta dapat memberikan penetalaksanaan terhadap penyakit tersebut. Sistem pakar juga dikatakan suatu aplikasi komputerisasi yang berusaha menirukan proses penalaran dari seorang ahli dalam memecahkan masalah spesifik dan membuat suatu keputusan atau kesimpulan karena pengetahuannya disimpan dalam basis pengetahuan untuk diproses pemecahan masalah.

Salah satu metode sistem pakar yaitu metode Dempster Shafer adalah suatu teori matematika untuk pembuktian berdasarkan belief function and plausible reasoning (fungsi kepercayaan dan pemikiran yang masuk akal yang digunakan untuk mengkombinasi potongan informasi yang terpisah (bukti) untuk mengkalkulasi kemungkinan dari suatu peristiwa. Dengan menggunakan sistem pakar diharapkan dapat mempercepat dalam mendiagnosa penyakit impetigo pada balita, sehingga dapat dengan mudah diketahui jenis penyakit yang sedang menjangkit. Secara umum teori dempster-Shafer ditulis dalam suatu interval Belief (Bel) adalah ukuran kekuatan evidence dalam mendukung dalam suatu himpunan proposisi. Jika bernilai 0 maka mengindikasikan bahwa tidak ada evidence, dan jika bernilai 1 menunjukkan adanya kepastian, dimana nilai bel yaitu (0-0.9). Dan Plausibility (Pl) dinotasikan sebagai: $\mathrm{Pl}(\mathrm{s})=1-\mathrm{Bel}(-\mathrm{s})$. Plausibility juga bernilai 0 sampai 1. Jika yakin akan $-\mathrm{s}$, maka dapat dikatakan bahwa Bel $(-s)=1$, dan $\mathrm{Pl}(-\mathrm{s})=0$. Dengan perhitungan metode membantu penyelesaian masalah diagnosa penyakit impetigo pada balita.

\section{METODOLOGI PENELITIAN}

\subsection{Sistem Pakar}

Pakar adalah orang yang memiliki pengetahuan, khusus, pendapat pengalaman dan metode, serta kemampuan untuk mengaplikasikan keahliannya tersebut guna menyelesaikan masalah[3]. Sistem Pakar (expert system)secara umum merupakan sistem informasi yang diprogram oleh komputer dengan memuat pengetahuan dari seorang pakar dan diterapkan untuk orang awam dalam menyelesaikan masalah maupun hanya sekedar mencari informasi tanpa harus berkonsultasi dengan seorang pakar.Tujuan sebenarnya sistem pakar bukan untuk menggantikan peran manusia, tetapi untuk memsubstitusikan pengetahuan manusia kedalam bentuk sistem, sehingga dapat digunakan oleh orang banyak.Sistem ini memanfaatkan kapabilitas penalaran untuk mencapai suatu simpulan. Sistem Pakar bisa juga dikatakan salah satu bidang teknik kecerdasan buatan yang diminati karena penerapannya diberbagai bidang baik dibidang ilmu pengetahuan maupun bisnis yang terbukti sangat membantu dalam mengambil keputusan dan penerapannya sangat luas. Sistem pakar didefinisikan sebagai aplikasi yang berbasis komputer dalam memecahkan masalah sebagaimana yang dipikirkan oleh pakar yang mempunyai keahlian khusus yang dapat menyelesaikan masalah yang tidak dapat diselesaikan oleh orang awam[4]. Secara umum, sistem pakar (Expert System)adalah sistem yang mampu menirukan pengetahuan manusia ke komputer dengan tujuan agar komputer dapat menyelesaikan permasalah seperti yang dilakukan oleh para ahli. Dengan adanya sistem ini, orang awam dapat menyelesaikan masalah yang sebenarnya hanya dapat diselesaikan dengan bantuan para ahli. Sistem pakar adalah sebuah aplikasi yang di rancang agar dapat digunakan untuk menyelesaikan sebuah masalah layaknya seorang pakar[5]. Sistem pakar adalah sebuah sistem yang kinerjanya memindahkan kemampuan yang dimiliki seorang pakar dalam bidang tertentu kedalam sistem atau program komputer yang disajikan dengan tampilan yang dapat digunakan oleh yang bukan pakar sehingga dengan sistem tersebut pengguna dapat membuat sebuah keputusan atau menentukan kebijakan layaknya seorang pakar[6]. Sistem pakar merupakan suatu sistem yang menggunakan pengetahuan manusia dimana pengetahuan tersebut dimasukkan ke dalam sebuah komputer dan kemudian digunakan untuk menyelesaikan masalah yang membutuhkan kepakaran atau keahlian manusia[7]. Sistem Pakar adalah program yang dapat memberi saran secara otomatis yang mencoba untuk menduplikasikan tahapan berpikir dan pengetahuan dari para ahli untuk mendapatkan sasaran dari sebah masalah yang dialami[8]. Sistem Pakar dibangun berdasarkan oleh dua bagian utama, yaitu lingkungan pengembang (development environment) yang digunakan dalam membangun komponen-komponen dan memperkenalkan pengetahuan kedalam basis pengetahuan (knowledge base)dan lingkungan konsultan (consultan environment)lingkungan berkonsultasi dalam mendapatkan ilmu pengetahuan dan anjuran seperti halnya berkonsultasi dengan seorang pakar[9]. Struktur sistem pakar didasarkan pada dua bagian utama sistem tersebut yakni lingkungan pengembang dan lingkungan konsultasi. Lingkungan pengembang merupakan bagian dalam memasukkan pengetahuan pakar kedalam sistem pakar, sedangkan lingkungan konsultasi merupakan lingkungan dimana pengguna memperoleh pengetahuan yang telah dimasukkan oleh pakar kedalam sistem pakar tersebut[10]. 


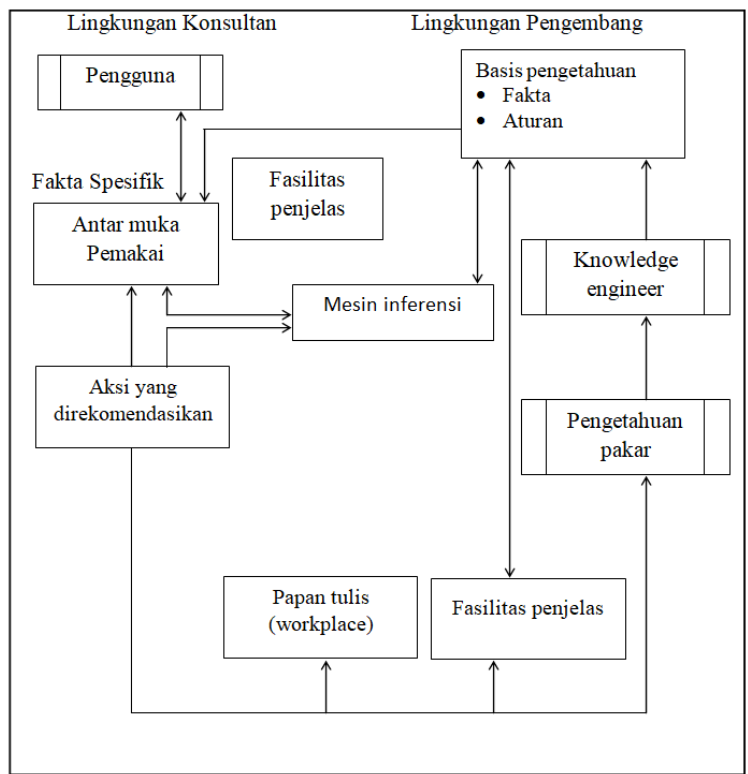

Gambar 1. Struktur Skema Sebuah Sistem Pakar[10].

\subsection{Dempster Shafer}

Dempster-Shafer pertama kali di perkenalkan oleh Dempster, yang melakukan percobaan model ketidakpastian dengan range probabilitas sebagai probabilitas tunggal. Kemudian pada tahun 1976 Shafer mempublikasikan teori Dempster tersebut pada sebuah buku yang berjudul Mathematical Theory of Evident'[11]. Dempster-Shafer merupakan teori matematika berdasarkan pada bukti dimana teori tersebut dapat memberikan suatu cara untuk mengkombinasikan bukti dari beberapa sumber dan memberikan tingkat kepercayaan yang didasarkan dari seluruh bukti yang ada[12]. Teori Dempster-Shafer adalah suatu teori matematika untuk pembuktian berdasarkan belief functions (fungsi kepercayaan) dan plausible reasoning (pemikiran yang masuk akal), yang digunakan untuk mengkombinasikan potongan informasi yang terpisah (bukti) untuk mengkalkulasikan kemungkinan dari suatu peristiwa'[13]. Teori Dempster-Shafer merupakan teori matematika dari bukti. Teori tersebut dapat memberikan sebuah cara untuk menggabungkan bukti dari beberapa sumber dan mendatangkan atau memberikan tingkat kepercayaan (direpresentasikan melalui fungsi kepercayaan) dimana mengambil dari seluruh bukti yang tersedia[14]. Teori ini dapat menunjukkan suatu cara membedakan bobot keyakinan yang disesuaikan dengan fakta yang ada. Teori ini juga dapat membedakan ketidakpastian dan ketidaktahuan. Dempster Shafer merupakan salah satu penalaran yang dapat menyelesaikan permasalahan ketidak konsistenan[15]. Teori Dempster Shafer memiliki beberapa karakteristik yang sesuai dengan cara berpikir seorang pakar, namun didasari dengan matematika yang kuat. Secara umum teori Dempster-Shaferditulis dalam suatu interval.

$$
\text { [Belief, Plausibility] }
$$

Belief (Bel) merupakan ukuran kekuatan evidencedalam mendukung suatu himpunan proposisi. Jika bernilai 0 maka mengindikasikan bahwa tidak ada evidence, dan jika m bernilai 1 menunjukan adanya nilai kepastian. Plausibility (P1) dinotasikan sebagai berikut:

$$
\mathrm{P} 1(\mathrm{~s})=1-\operatorname{Bel}(-\mathrm{s})
$$

Plausibilityakan mengurangi tingkat kepercayaan dari evidence.

Pada teori Dempster-Shafermemiliki frame of discrement $(\theta)$. Frame tersebut bertujuan untuk mengaitkan ukuran kepercayaan elemen-elemen $\theta$. Tidak semua evidencesecara langsung mendukung setiap elemen-elemen, maka sebab itu diperlukan adanya probabilitas fungsi densitas $(\mathrm{m})$.Nilai $\mathrm{m}$ tidak hanya mendefinisikan elemen-elemen $\theta$ saja, namun juga semua subsetnya.Sehingga jika $\theta$ berisi n elemen, maka subset $\theta$ adalah $2 \mathrm{n}$. Jumlah semua $\mathrm{m}$ dalam subset $\theta$ sama dengan 1. Apabila tidak ada informasi apapun maka nilai $\mathrm{m}\{\theta\}=1,0$. Apabila diketahui $\mathrm{X}$ merupakan subset dari $\theta$, dengan $\mathrm{m} 1$ sebagai fungsi densitasnya, dan Y juga merupakan subset dari $\theta$ dengan $\mathrm{m} 2$ sebagai fungsi densitasnya, maka dapat dibentuk fungsi kombinasi m1 dan m2 sebagai m3[11][12], yaitu:

$$
\operatorname{M3}(Z)=\frac{\sum X \cap Y=Z m 1(X) m 2(y)}{1-\sum X \cap Y=\theta m 1(X) m 2(Y)}
$$

Keterangan :

M1 = densitas untuk gejala pertama

M2 = densitas untuk gejala kedua

M3 = kombinasi dari kedua densitas diatas

$\theta=$ semesta pembicara dari sekumpulan hipotesis $\left(\mathrm{X}^{\prime}\right.$ dan $\left.\mathrm{Y}^{\prime}\right)$

$\mathrm{X}$ dan $\mathrm{y}=$ subset dari $\mathrm{ZX}$ ' dan $\mathrm{y}^{\prime}=$ subset dari $\theta$. 
Tabel 1. Nilai kemungkinan antara Belief dan Plausibility

\begin{tabular}{cl}
\hline Evidential Interval & \multicolumn{1}{c}{ Pengertian } \\
\hline$[1,1]$ & Sepenuhnya benar \\
{$[0,0]$} & Sepenuhnya salah \\
{$[0,1]$} & Sepenuhnya tidak diketahui \\
{$[$ Bel, 1$]$ dimana $0<\mathrm{Bel}<1$} & Cenderung mendukung \\
{$[0$, Pls $]$ dimana $0<$ Pls $<1$} & Cenderung menolak \\
{$[$ Bel,Pls $]$ dimana $0<$ BelPls $<1$} & Cenderung mendukung dan menolak \\
\hline
\end{tabular}

\section{HASIL DAN PEMBAHASAN}

Dalam menyelesaikan permasalahan yang terjadi tentang mendiagnosa penyakit impetigo berdasarkan gejalagejala yang terjadi pada balita maka dibutuhkan suatu sistem yang mampu mengadopsi proses dan cara berfikir seorang pakar yang nantinya dapat diaplikasikan dalam sebuah sistem komputer dengan menggunakan metode Dempster Shafer.

Adapun tahap algoritma sistem dalam proses diagnosa terhadap penyakit impetigo pada balita dengan menggunakan metode Dempster Shafer yaitu sebagai berikut[8]:

1. Pembuatan basis pengetahuan

2. Membuat inisialisasi nilai densitas dan data gejala

3. Menerapkan metode Dempster Shafer pada diagnosa penyakit impetigo pada balita

4. Menetapkan hasil atau keputusan

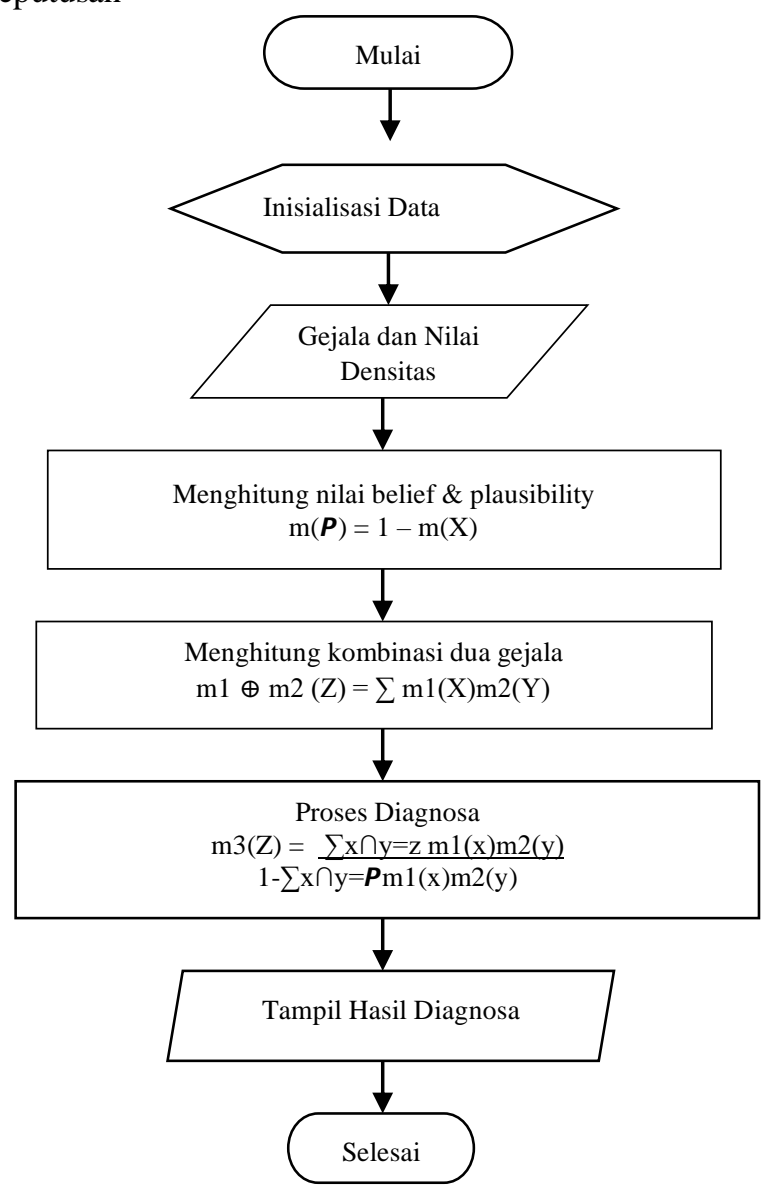

Gambar 2. Flowchart Algoritma

\subsection{Basis Pengetahuan}

Basis pengetahuan merupakan bagian dari proses akuisisi pengetahuan teknis basis pengetahuan yang digunakan pada rekayasa pakar ini adalah dengan menggunakan aturan produksi (rule base knowledge). Dimana pengetahuan di representasikan dalam bentuk fakta dan Rule. Pengetahuan dalam sistem direpresentasikan oleh himpunan kaidah dalam bentuk fakta IF-THEN. Disini pengetahuan disajikan dalam aturan-aturan yang berbentuk pasangan keadaan aksi (condition-action) "Jika (IF) keadaan terpenuhi atau terjadi MAKA (THEN)". Suatu aksi akan terjadi. Langkah yang dibuat untuk basis pengetahuan sistem pakar ini adalah pengumpulan 
data-data yang diperoleh dari hasil survei di Rumah Sakit Umum H. Adam Malik, Medan. Wawancara yang berhubungan dengan penyakit Impetigo pada balita.

Tabel 2. Data Gejala Impetigo

\begin{tabular}{cll}
\hline No & Kode Gejala & Gejala Penyakit \\
\hline 1 & G1 & $\begin{array}{l}\text { Bengkak didaerah kelenjar getah bening (limfa) (leher, tulang selangka, } \\
\text { ketiak,dan pangkal paha) } \\
\text { Benjilan (bula) mudah pecah dan membentuk collarete (luka dangkal dengan } \\
\text { sisik ditepi) } \\
\text { Gatal, Sakit }\end{array}$ \\
3 & G2 & Bintil-bintil merah atau lepuhanlembut berisi cairan atau nanah yang mudah \\
4 & Gecah \\
5 & G5 & Ruam kemerahan dengan bintil merah kecilberisi cairan \\
6 & G6 & Koreng berwarna kuning seperti madu dan berminyak \\
7 & G7 & Gatal, kadang sakit \\
8 & G8 & Kadang demam \\
9 & G9 & Luka di dahi, wajah, hidung dan bahu \\
\hline (Sumber: Rumah Sakit Umum H. Adam Malik, Medan)
\end{tabular}

Data-data jumlah diagnosa penyakit yang digunakan dalam sistem pakar jenis penyakit impetigo ini berjumlah 2 macam penyakit yaitu:

Tabel 3. Data Penyakit Impetigo

\begin{tabular}{lll}
\hline No & Kode Penyakit & Nama Penyakit \\
\hline 1 & P1 & Penyakit Impetigo Krustosa \\
2 & P2 & Penyakit Impetigo Bulosa \\
\hline
\end{tabular}

Setelah mengetahui sumber pengetahuan mengenai gejala penyakit impetigo pada balita, tahap selanjutnya menentukan nilai densitas dari gejala dan diagnosis penyakit tersebut:

Tabel 4. Nilai Densitas Gejala Penyakit Impetigo

\begin{tabular}{llll}
\hline No & Kode Gejala & Gejala Penyakit & Nilai Densitas \\
\hline 1 & G1 & $\begin{array}{l}\text { Bengkak didaerah kelenjar getah bening (limfa) (leher, tulang } \\
\text { selangka, ketiak, dan pangkal paha) } \\
\text { Benjilan (bula) mudah pecah dan membentuk collarete (luka } \\
\text { dangkal dengan sisik ditepi) }\end{array}$ & 0,3 \\
3 & G2 & Gatal, Sakit & 0,9 \\
4 & G3 & Bintil-bintil merah atau lepuhanlembut berisi cairan atau nanah & 0,5 \\
5 & G5 & yang mudah pecah & 0,8 \\
6 & G6 & Ruam kemerahan dengan bintil merah kecilberisi cairan & 0,9 \\
7 & G7 & Koreng berwarna kuning seperti madu dan berminyak & 0,8 \\
8 & G8 & Katal, kadang sakit & 0,5 \\
9 & G9 & Luka di dahi, wajah, hidung dan bahu & 0,4 \\
\hline
\end{tabular}

Dari gejala dan jenis diagnosa penyakit impetigo yang diketahui maka dapat disimpulkan basis pengetahuan berupa hubungan antara gejala dan jenis diagnosa penyakit impetigo pada balita. Basis pengetahuan dapat dilihat pada tabel 5 di bawah ini:

Tabel 5. Basis Pengetahuan

\begin{tabular}{|c|c|c|c|c|}
\hline No & Kode Gejala & Gejala Penyakit & P1 & $\mathrm{P} 2$ \\
\hline 1 & G1 & $\begin{array}{l}\text { Bengkak didaerah kelenjar getah bening (limfa) (leher, tulang } \\
\text { selangka, ketiak,dan pangkal paha) }\end{array}$ & & $\sqrt{ }$ \\
\hline 2 & G2 & $\begin{array}{l}\text { Benjilan (bula) mudah pecah dan membentuk collarete (luka } \\
\text { dangkal dengan sisik ditepi) }\end{array}$ & & $\sqrt{ }$ \\
\hline 3 & G3 & Gatal, Sakit & $\sqrt{ }$ & \\
\hline 4 & G4 & $\begin{array}{l}\text { Bintil-bintil merah atau lepuhanlembut berisi cairan atau nanah } \\
\text { yang mudah pecah }\end{array}$ & & $\sqrt{ }$ \\
\hline 5 & G5 & Ruam kemerahan dengan bintil merah kecilberisi cairan & $\sqrt{ }$ & \\
\hline 6 & G6 & Koreng berwarna kuning seperti madu dan berminyak & $\sqrt{ }$ & \\
\hline 7 & G7 & Gatal, kadang sakit & & $\sqrt{ }$ \\
\hline 8 & G8 & Kadang demam & $\sqrt{ }$ & \\
\hline
\end{tabular}




\subsection{Penerapan Metode Dempster Shafer}

Dempster Shafer merupakan nilai yang diberikan untuk menunjukkan besarnya kepercayaan. Dimana nilai (m) suatu gejala yang diinput antara (0-1) dengan menerapkan persamaan 3 [15] :

Seorang balita menderita penyakit kulit, dimana balita tersebut diduga terserang penyakit kulit yang belum diketahui penyakit kulit tersebut. Untuk memastikan mengenai gejala-gejala penyakit yang dialaminya yaitu sebagai berikut adanya bengkak didaerah kelenjar getah bening (limfa) (leher, tulang selangka, ketiak, dan pangkal paha (g01), gatal, sakit (g03), dan bintil-bintil merah atau lepuhanlembut berisi cairan atau nanah yang mudah pecah (g04) maka dilakukan perhitungan dempster shafer sebagai berikut :

Langkah pertama hitung nilai belief \& disbelief hostile dari gejala g01 yaitu "bengkak didaerah kelenjar getah bening (limfa) (leher, tulang selangka, ketiak,dan pangkal paha yang terkena impetigo" yang merupakan diagnosa dari penyakit impetigo, yang ada pada diagnosa ( 1 1, dan $\mathrm{p} 2$ ). Adapun yang digunakan untuk melakukan diagnosa adalah:

$$
\begin{gathered}
\mathrm{m}_{1}(\mathrm{G} 01)=0,3 \\
\mathrm{~m}_{1}(\theta)=1-\mathrm{m}_{1}(\mathrm{G} 01)=1-0,3=0,7
\end{gathered}
$$

Kemudian G03“Gatal, Sakit” yang ada pada diagnosa (P1,P2) maka hitung juga belief \& disbelief hostlife :

$$
\begin{gathered}
\mathrm{m}_{2}(\mathrm{G} 03)=0,5 \\
\mathrm{~m}_{2}(\theta)=1-\mathrm{m}_{1}(\mathrm{G} 03)=1-0,5=0,5
\end{gathered}
$$

Maka setelah G01, G03 didapat maka dilakukan kombinasi perhitungan terhadap dua gejala yang dialami, dengan rumus Dempster Shafer rule of combination dibawah jika diilustrasikan dapat dilihat table 6:

Tabel 6. Aturan Kombinasi $\mathrm{m}_{3}$

\begin{tabular}{lll}
\hline & $\mathrm{m}_{2}\{\mathrm{P} 1\}=0,5$ & $\mathrm{~m}_{2}\{\theta\}=0,5$ \\
\hline $\mathrm{m}_{1}\{\mathrm{P} 2\}=0,3$ & $\{\theta\}=0,15$ & $\{\mathrm{P} 2\}=0,15$ \\
$\mathrm{~m}_{1}\{\theta\}=0,7$ & $\{\mathrm{P} 1\}=0,35$ & $\{\theta\}=0,35$ \\
\hline
\end{tabular}

Setelah itu maka dapat dilihat dari kepercayaan terhadap diagnosa yang dialami dengan menggunakan rumus Dempster Shafer rule of combination.

$$
\begin{array}{lll}
\mathrm{m}_{3}(\mathrm{P} 1) & =\frac{0,35}{1-0,15} & =0,41176470588 \\
\mathrm{~m}_{3}(\mathrm{P} 2) & =\frac{0,15}{1-0,15} & =0,17647058824 \\
\mathrm{~m}_{3}(\theta) & =\frac{0,35}{1-0,15} & =0,41176470588
\end{array}
$$

Kemudian G04 yaitu "Bintil-bintil merah atau lepuhanlembut berisi cairan atau nanah yang mudah pecah " maka nilai keyakinannya adalah :

$$
\begin{gathered}
\mathrm{m}_{4}(\mathrm{G} 04)=0,8 \\
\mathrm{~m}_{4}(\theta)=1-\mathrm{m}_{3}(\mathrm{G} 04)=1-0,8=0,2
\end{gathered}
$$

Maka setelah G01,G03,G04, didapat maka dilakukan kobinasi perhitungan dengan rumus Dempster Shafer rule of combination dibawah

Tabel 7. Aturan kombinasi $\mathrm{m}_{5}$

\begin{tabular}{ccc}
\hline & $\mathrm{m}_{4}\{\mathrm{P} 2\}=0,8$ & $\mathrm{~m}_{4}\{\theta\}=0,2$ \\
\hline $\mathrm{m}_{3}\{\mathrm{P} 1\}=0,41176470588$ & $\{\theta\}=0,3294117647$ & $\{\mathrm{P} 1\}=0,08235294118$ \\
$\mathrm{~m}_{3}\{\mathrm{P} 2\}=0,17647058824$ & $\{\mathrm{P} 2\}=0,14117647059$ & $\{\mathrm{P} 2\}=0,03529411765$ \\
$\mathrm{~m}_{3}\{\theta\}=0,41176470588$ & $\{\mathrm{P} 2\}=0,3294117647$ & $\{\theta\}=0,08235294118$ \\
\hline
\end{tabular}

Setelah itu maka dapat dilihat dari kepercayaan terhadap diagnosa yang dialami dengan menggunakan rumus Dempster Shafer rule of combination

$$
\begin{aligned}
& M_{5}\{\mathrm{P} 1\}=\frac{0,08235294118}{1-0,3294117647}=0,12280701755 \\
& M_{5}\{\mathrm{P} 2\}=\frac{0,14117647059+0,3294117647+0,03529411765}{1-0,3294117647}=0,7543859649 \\
& M_{5}\{\theta\}=\frac{0,08235294118}{1-0,3294117647}=0,12280701755
\end{aligned}
$$

Nilai keyakinan yang paling kuat adalah terhadap penyakit $\{\mathrm{P} 2\}$ yaitu sebesar 0,7543859648 (75\%) yang didapatkan dari G01, G03, G04. 


\section{KESIMPULAN}

Untuk menerapkan metode Dempster Shafer pada sistem pakar yaitu dengan terlebih dahulu membuat basis pengetahuan, membuat inisialisasi nilai densitas, data gejala, menerapkan metode Dempster Shafer pada diagnosa penyakit impetigo, dan kemudian mendapatkan nilai hasil atau keputusan. Dari analisis metode di atas dapat dibuat sebuah sistem Untuk merancang aplikasi sistem pakar untuk mendiagnosa penyakit impetigo pada balita dengan menggunakan metode Dempster Shafer yaitu dengan merancang Use Case diagram, Activity diagram, Class diagram, Flowchart program, kemudian merancang basis data, data dimaksudkan disimpan dalam database yang diorganisasikan oleh suatu sistem dengan sistem manajemen pangkalan data ( Database Management System/DBMS). Melalui pangkalan data inilah data dapat diambil dan diekstrasi dengan cepat[16].Sistem pakar ini dapat membantu diagnosa penyakit Impetigo berdasarkan gejala yang diderita oleh balita dan memberikan solusi untuk mengatasi gejala tersebut.

\section{UCAPAN TERIMAKASIH}

Terima kasih disampaikan kepada STMIK Triguna Dharma selaku homebase peneliti yang telah memberikan dukungan secara moril dan materi, terima kasih kepada Bapak Moch. Iswan Perangin Angin yang telah berkontribusi atas penelitian ini, serta tak lupa pula ucapan terima kasih kepada Bapak Marsono yang juga ikut berkontribusi atas penelitian ini dan juga selaku Kaprodi Sistem Informasi yang terus mendukung setiap dosen dalam melakukan penelitian. Serta ucapan terima kasih kepada Bapak/Ibu yang mengelolah jurnal Media Informatika Budidarma yang telah meluangkan waktu untuk meriview penelitian ini, dan besar harapan kami agar kerjasama dalam penerbitan artikel antara STMIK Triguna Dharma dengan Budidarma terus berjalan dengan baik.

\section{REFERENCES}

[1] M. S. Aprilina, D. P. Nastiti, A. D. Putriandani, and R. Hestiningsih, "Metode Plester Herbal Berbahan Bunga Teratai ( Nelumbium Nelumbo Druce ) Bagi Penderita Impetigo," Ilm. Mhs., vol. 2, no. 2, pp. 106-110, 2012.

[2] S. Azhar, H. Latipa, S. Leni, and N. Zulita, "Sistem Pakar Penyakit Ginjal Pada Manusia Menggunakan Metode Forward Chaining," J. Media Infotama, vol. 10, no. 1, pp. 16-26, 2016.

[3] L. Septiana, "Perancangan Sistem Pakar Diagnosa Penyakit Ispa Dengan Metode Certainty Factor Berbasis Android," None, vol. 13, no. 2, pp. 1-7, 2016.

[4] S. Sibagariang, "Sistem Pakar Diagnosa Penyakit Sapi Dengan Metode Certainty Factor Berbasis Android," J. TIMES, vol. 3, no. 2, pp. 35-39, 2008.

[5] L. A. Latumakulita, "SISTEM PAKAR PENDIAGNOSA PENYAKIT ANAK MENGGUNAKAN CERTAINTY FACTOR ( CF ) EXPERT SYSTEM FOR DIAGNOSING CHILD DISEASE."

[6] W. Wardiana and V. V. Tobing, “Aplikasi Sistem Pakar Tes Kepribadian Berbasis Web,” pp. 99-103.

[7] M. Dahria, Muhammad; Silalahi, Rosinda; Ramadhan, "SISTEM PAKAR METODE DEMPSTER SHAFER UNTUK MENENTUKANJENIS GANGGUAN PERKEMBANGAN PADA ANAK," J. Ilm. SAINTIKOM, vol. 12, no. 1, pp. $1-10,2013$.

[8] I. Akil, "Analisa Efektifitas Metode Forward Chaining Dan Backward Chaining Pada Sistem Pakar," None, vol. 13, no. 1, pp. 35-42, 2017.

[9] P. Putri and H. Mustafidah, "Sistem Pakar Untuk Mendiagnosa Penyakit Hati Menggunakan Metode Forward Chaining," JUITA J. Inform., vol. I, no. 4, pp. 143-155, 2011.

[10] H. Nurwarsito, "Sistem Informasi Jadwal Perkuliahan dengan Metode Sistem Pakar," Eeccis, vol. III, no. 1, pp. 57-61, 2009.

[11] M. D. Sinaga and N. S. B. Sembiring, "Penerapan Metode Dempster Shafer Untuk Mendiagnosa Penyakit Dari Akibat Bakteri Salmonella," CogITo Smart J., vol. 2, no. 2, p. 94, 2016, doi: 10.31154/cogito.v2i2.18.94-107.

[12] R. M. Simanjorang, "Perancangan sistem pakar dalam mengidentifikasi tanaman beracun menggunakan metode dempster shaper," vol. 1, no. 2, pp. 134-138, 2017.

[13] R. Hamidi, H. Anra, and H. S. Pratiwi, "Analisis Perbandingan Sistem Pakar Dengan Metode Certainty Factor dan Metode Dempster-Shafer Pada Penyakit Kelinci," J. Sist. dan Teknol. Inf., vol. 5, no. 2, pp. 142-147, 2017.

[14] E. R. Ritonga and M. D. Irawan, "Sistem Pakar Diagnosa Penyakit Paru-Paru," J. Comput. Eng. Syst. Sci., vol. 2, no. 1, pp. 39-47, 2017, doi: https://doi.org/10.24114/cess.v2i1.7179.

[15] E. Wahyuni and W. Prijodiprojo, "Prototype Sistem Pakar untuk Mendeteksi Tingkat Resiko Penyakit Jantung Koroner dengan Metode Dempster-Shafer (Studi Kasus: RS. PKU Muhammadiyah YOGYAKARTA)," Berk. Ilm. MIPA, vol. 23, no. 2, p. 242752, 2013.

[16] A. H. Nasyuha, "Sistem Pendukung Keputusan Dalam Memasarkan Produk Kulkas Pada Toko Elektronik City Menggunakan Metode AHP Berdasarkan Merek dagang,” vol. 17, no. 1, pp. 78-91, 2018. 